\title{
Small needles for big surgery?
}

\author{
Francois Dagenais, MD
}


Quebec, Canada.

Disclosures: Author has nothing to disclose with regard to commercial support.

Received for publication Dec 18, 2017; accepted for publication Dec 27, 2017; available ahead of print Feb 1, 2018.

Address for reprints: Francois Dagenais, MD, Department of Cardiovascular Surgery, Institut universitaire de cardiologie et pneumologie de Québec (IUCPQ), 2725 chemin, Quebec City, Quebec G1V 4G5, Canada (E-mail: francois.dagenais@chg.ulaval.ca).

J Thorac Cardiovasc Surg 2018;155:1371

$0022-5223 / \$ 36.00$

Copyright (C 2018 by The American Association for Thoracic Surgery

https://doi.org/10.1016/j.jtcvs.2017.12.093
}

Type A dissection is a catastrophic and lethal event. Although advances in operative techniques have contributed to improve outcome in complex elective surgeries of the thoracic aorta, mortality for type A dissection still remains high. A recent International Registry of Acute Aortic Dissection data review reports a $17 \%$ to $26 \%$ operative mortality for type A dissection. ${ }^{1}$ In the current issue of the Journal, Yang and colleagues ${ }^{2}$ reports a singlesurgeon series of 94 consecutive patients operated for type A aortic dissection between 2012 and 2016. Results are excellent with a hospital mortality of $7 \%$. At a follow-up of $22 \pm 17$ months, no pseudoaneurysm was documented, root repair remained stable, and distal aortic growth was minimal with a thrombosed distal false lumen in $55 \%$ of patients. The article highlights 2 important facts: adherence to basic surgical principles for type A dissection and experience.

Yang stresses the importance of sewing the dissected layers together using 5-0 Prolene and telescoping the Dacron graft within the aorta without the adjunct of BioGlue (CryoLife Inc, Kennesaw, Ga) or Teflon felt. Such surgical principles for type A dissection have been outlined by historical articles of the 1970s. ${ }^{3,4}$ Thus, the current article reemphasizes the basic principles for a successful type A repair: (1) meticulous reapproximation of the dissected layers avoiding iatrogenic intimal tears; (2) graft to intima apposition; and (3) valve resuspension when feasible. Respecting these principles, use of BioGlue or Teflon felt is unnecessary, obviating the potential complications of pseudoaneurysm formation or emboli mainly reported with BioGlue.

Although adherence to these surgical principles is a prerequisite to a good outcome, the excellent results of the current series are probably more linked to experience than 5-0 Prolene. Series of high-volume aortic centers have consistently reported lower mortality in type A dissection compared with large registries encompassing combined results of multiple lower-volume centers. Outcome of elective surgery of the thoracic aorta has derived great benefit by the



Francois Dagenais, MD
Central Message
Rapid transfer to high-volume centers with
around-the-clock dedicated aortic teams should
be the current standard to improve surgical re-
sults of patients with type A aortic dissection.

See Article page 1360. development of dedicated teams. Type A dissection is no different! Convincing data support improvement in operative outcomes for type A dissection by establishing dedicated aortic teams. ${ }^{5}$ Furthermore, investigation of new complex procedures such as the "frozen elephant trunk" in type A dissection may provide a midterm advantage for type A patients, thus increasing surgical expertise required to perform these operations. Factors such as delay to access the operating room, hemodynamic instability/tamponade, malperfusion, and advanced age/comorbidities will always negatively affect the surgical outcomes of type A dissection. However, rapid transfer to high-volume centers with around-the-clock dedicated aortic teams should be the current standard to improve surgical results of patients with type A aortic dissection. Yang and colleagues ${ }^{2}$ should be congratulated on establishing such a dedicated team model with excellent results.

\section{References}

1. Berretta P, Patel HJ, Gleason TG, Sundt TM, Myrmel T, Desai N, et al. IRAD experience on surgical type A acute dissection patients: results and predictors of mortality. Ann Cardiothorac Surg. 2016;5:346-51.

2. Yang B, Malik A, Waidley V, Wu X, Norton EL, Williams DM, et al. Short-term outcomes of a simple and effective approach to aortic root and arch repair in acute type A aortic dissection. J Thorac Cardiovasc Surg. 2018;155:1360-70.

3. Daily PO, Trueblood HW, Stinson EB, Wuerflein RD, Shumway NE. Management of acute aortic dissections. Ann Thorac Surg. 1970;10:237-47.

4. Miller DC, Stinson EB, Oyer PE, Rossiter SJ, Reitz BA, Griepp RB, et al. Operative treatment of aortic dissections: experience with 125 patients over sixteenyear period. J Thorac Cardiovasc Surg. 1979;78:365-82.

5. Andersen ND, Benrashid E, Ross AK, Pickett LC, Smith PK, Daneshmand MA, et al. The utility of the aortic dissection team: outcomes and insights after a decade of experience. Ann Cardiothorac Surg. 2016;5:194-201. 